\title{
TAKING THE E-TRAIN IN UNIVERSITY EDUCATION
}

\author{
Directions for Research
}

\author{
Anne McDougall, Ted Clark and Lyn Campbell \\ Department of Science and Mathematics Education, The University of Melbourne. Victoria \\ 3010, Australia
}

\begin{abstract}
This paper looks at the increased use of e-learning in university education. Acknowledging the origins of the term in business and industry settings, it outlines features of e-learning in university contexts. It suggests some directions for research on the use of e-learning in university education, particularly arguing for research endeavour focused on issues specific to what is novel in e-learning, but building on findings from educational research in earlier more limited technological environments.
\end{abstract}

Key words: higher education, research, open learning.

\section{INTRODUCTION}

While the use of the term 'e-learning' originated in business and industry training contexts, many universities now offer online courses and degrees, describing their strategies for teaching and learning as following the 'principles of e-learning' (e.g., Laurillard \& McAndrew, 2002; Mason, 2002). These principles include many of the features that were previously claimed for online learning and distance education, or virtual teaching and learning environments. This paper is interested in the issue of whether elearning should be identified as a business strategy or has some origin in educational research and practice. Further the paper argues for close scrutiny of related claims made by some that e-learning provides or requires a new kind of learning (ASTD \& NGA, 2001; Mason, 2002).

The paper looks briefly at the origins of the term e-learning, considers its transition into university settings, and examines the extent and ways in 
which this provides a truly novel approach in university education. It argues that research should focus on aspects of e-learning that are truly novel while building on findings from previous research.

The term e-learning has been used in training contexts for some years. Previously, computer-based training commonly involved an individual learner working at a computer, typically with material presented on CDROM. While e-learning does not exclude CD-ROM-based materials, it is now often characterised by distributed, team-based knowledge creation and sharing. In some business profiles this approach supports what Senge (1992) called the 'learning organisation'.

This does not mean these organisations are trying to become organisations for learning like universities. By contrast the practice of learning using the e-learning label as a foundation for the development of a 'learning organisation' may be an alternative to, or in opposition to, the lectures, tutorials and practical classes most commonly associated with academic learning in university settings. In such learning organisations, the role of e-learning is to empower employees to confront and manage change by providing them with access to appropriate situated lifelong learning resources, often in a 'just in time' mode.

\section{E-LEARNING AND UNIVERSITY EDUCATION}

Given the extensive involvement universities have had in pioneering and developing the use of technologies for learning, it is appropriate for universities looking to utilise e-learning approaches, to consider what aspects of it are similar to previous types of technology enhanced learning, particularly where these aspects have already been well researched.

In academia, as in industry, there is much use of the available technologies to support informal learning opportunities, with an emphasis on promoting networking among professionals. This is evidenced by the widespread and extensive use of e-mail and the World Wide Web for these purposes. Industry and academic advocates of e-learning both draw on beliefs that social interaction aids in the construction of knowledge, and see information and communication technologies as a natural ally in this. This focus, can be attributed on the business side to the convergence of management theories emphasizing systems thinking (Senge 1992), knowledge management (Brown \& Duguid, 2000) and organisational learning (Argyris \& Schon, 1996). On the academic side it developed alongside learning theories emphasising situated learning (Lave \& Wenger, 1991), distributed learning (Salomon, 1993) and communities of practice/learners (Wenger, 1998). Collis (1994) highlighted the similarities 
in concerns with learning between industry's use of computer supported cooperative work and education's computer supported cooperative learning.

\section{WHAT IS NEW IN UNIVERSITY E-LEARNING?}

In universities the term e-learning is used to describe a range of technology-related teaching activities, such as the enhancement of traditional campus-based learning with the integration of course related material on websites (Palloff \& Pratt, 2001). E-learning, as a term, is a way of referring to a new integrated communication approach that is not limited to previous online access or presentation based modes that are now seen as predominantly one-way, delivery-only systems. It is particularly used to describe the use of internet-based technology to enable provision of teaching and learning activities that can cater for students in geographically different locations, learning at different times. This includes a recognition that tailoring relevant courses of study requires access to materials, other students, lecturers and tutors in ways that may not be timetable or place dependent. Although this is consistent with some of the just in time goals of industry based e-learning, in university contexts it is likely to follow a more traditional approach, setting out a course of study with lecture materials, references, assessable tasks and online student-lecturer discussions; it follows a lecture/tutorial/essay system that, although online, is familiar to any campus based university student (Salmon, 2000; Laurillard \& McAndrew, 2002). What is regarded as new and different in the university e-learning approach is the value placed on the interpersonal communicative aspects of e-learning, in contrast to the earlier web-based learning approaches that used the technology primarily for access to and interaction with course content (Garrison \& Anderson, 2003).

Criticism of e-learning at university levels extends from arguments that e-learning is simply a new name for already existing online learning practices (Mason, 2002), to studies that identify online teaching and learning approaches at university level as operating to the detriment of other forms of face to face teaching and learning at university (Brabazon 2002). Authors such as Hara and Kling (2000) and Mann (2003) criticise online learning practices that do not have a social component. Greenagel (2002) identifies the failure of much online teaching to embrace constructivist pedagogies.

In this context of reappraisal of online learning and its value for higher education it must be acknowledged that the term e-learning is used with some variety of meaning in university education. Re-visiting the motivations for adoption of e-learning outlined earlier, we note that little there is genuinely novel. Many attempts have already been made to increase the 
effectiveness and efficiency of education through computer use, and claims that the use of technology might enable new kinds of learning have been made more than occasionally throughout the history of educational computing (Hiltz, 1998; Clark, 2000). Further, research into the use of elearning environments may well provide an opportunity to elucidate, in social and collaborative situations, the complex processes of learning itself but it has not yet been established that the form of learning required is substantially different from general principles of learning in social settings.

\section{RESEARCH ISSUES IN E-LEARNING FOR UNIVERSITY EDUCATION}

The development of e-learning in university education must of course be accompanied and informed by sound research. In this context we argue the importance of an awareness of previous work in educational computing. Research on e-learning in university education should utilise the findings of research using earlier technologies and take this further by focusing on what is different in e-learning environments. A suggestion would be to specifically look at those aspects of learning that might be associated with the increasing sophistication of technologies. Findings from earlier work, for example, on issues in human-computer interaction and interface design for learning, might well apply as appropriately in contemporary technological contexts but screen layout and amounts of material presented might also take into consideration better screen resolution and faster delivery of multimedia material. Similarly, behaviourist approaches to computer-based learning found to be ineffective with early computers will not necessarily be more effective if presented with the improved "colour and movement" available now.

It is beyond the scope of this paper to attempt to delineate a full range of research issues for e-learning in university education; we shall use just some examples to illustrate the approach we advocate.

Consider the issue of the use of online Learning Management Systems (LMSs) in university e-learning. Some lecturers take on board the LMS approach, utilising the modular structure and management facilities provided to present to students the material and activities for a course. In our experience, others prefer to develop their own distinctive, possibly idiosyncratic on-line materials and activities, in ways determined perhaps by the nature of the ideas and concepts to be studied in the course, or by the lecturer's preferred teaching style and strategies, or by a desire to provide a particular type of learning environment. LMSs are software environments into which teachers without programming expertise can enter and manage 
learning content and enrolments, but these are not new; the author language environments of the 1970s were designed for exactly this purpose. Early computer-managed learning systems attempted to carry out many of the learning management functions of the present online learning management systems. In the light of the failure of author languages and computermanaged learning systems to gain widespread use or to provide environments for any notable improvement in understanding of, or practice in university education, research into whether standardised learning management systems interfere with content or learning contexts or preferred styles in e-learning is clearly warranted. Documented reasons for lecturer resistance to author language use should be re-examined in terms of the now more sophisticated LMSs. Walsh (Walsh, 2000) suggests that teachers' resistance is linked to more than technological issues, and includes concerns about pedagogy, critical literacies, industrial implications and the socioemotional transitions linked with change.

An important issue for consideration by university teachers developing elearning courses is the extent to which the online course can or should imitate or differ from traditional campus-based teaching (McDonald, 1995). Some work here suggests that even with deliberate attempts to make the elearning experience as similar as possible to the on-campus one, achieving this is very difficult, perhaps impossible. Indications are that the new technologies are not only different learning environments but the content that can be covered in those environments is different from that covered in more traditional university settings (Murnane, 2003; Mason, 2002). We should note from earlier research on technology-supported learning environments that simple experimental studies comparing the "new" with "traditional" methods inevitably reveal few if any significant differences, and tell us very little that is of value. More complex, usually qualitative studies are far more likely to provide useful findings in this area.

Another aspect of e-learning that is associated with established educational theory is group interaction enabled by online discussion (Laurillard \& McAndrew, 2002). Again early work indicates that online discussion does not (cannot) duplicate tutorial or face to face student interaction (Hara \& Kling, 2000). Content is accessed differently online and course material can be integrated more easily into online discussion and online teaching and learning environments via the ability all participants have of including hyperlinks to references and support material. The process of integration of direct links to content into online discussions certainly reduces the fluidity of ideas and responses, if the more traditional face to face discussion is taken as the model for what online discussion should be attempting to achieve. It also suggests discussion is based on solid easily verified hyperlinked referencing and therefore a difference in content that is 
covered (Murnane, 2003) and also a possible increase in the burden of participating (Hara \& Kling, 2000; Mann, 2003). This is certainly an area where research in group based learning might uncover novel elements in what e-learning contributes or subtracts from this learning approach.

Hiltz (1998) points out that online discussion can potentially be more engaging, more inclusive, and perhaps more democratic than in face to face situations. Shy, less verbally articulate, slight of voice or slower respondents can spend time considering their responses before submitting them and have equal access being displayed online. In addition participation online may be made mandatory to indicate attendance (Clark, 2003).This does indicate, as mentioned, an increase in the workload for participants in relation to providing considered, well referenced online contributions (Hara \& Kling, 2000; Mann, 2003). But it also means that research into less burdensome participation in e-learning at university level is warranted (Clark, 2003).

Inclusive participation in e-learning, taking advantage of hyper linking content by participants and teachers, suggests a need for further research into a mix of pedagogies around questions of interpersonal communication and the text and hypertext based group processes that are available online via online discussion, chat, email, and now text messaging and online video conferencing. In part the investigation of this question is about how elearning might provide more engaging, direct and active ways to integrate content into the online communication between participants. Garrison and Anderson (2003) point to the importance of access not only to information but also to what they call online "social presence". This engaging of social presence needs investigation in relation to how higher education might utilise what is appropriate from the business community's use of e-learning to support knowledge management and Senge's (1992) notions of the 'learning organisation'.

Related to the above examples are investigations of such things as: aspects of lecturers' and students' work associated with e-learning including time demands for course development, delivery, maintenance and participation; the nature of the activities required for assessment; effects of increased use of e-learning on campus-based learning and teaching; strategies for use of constructivist approaches to learning and teaching; appropriate amounts and types of interactivity, and variations in this among students. Further, the ability afforded by computer technology to record processes, where previously only products of learning were easily available to researchers, has enabled research into learning processes and individual differences that may be able to advance research of collaborative and informal learning. 


\section{CONCLUSION}

What the term e-learning provides for higher education is not a complete break with past uses of technologies in education and research. Business and industry's application of e-learning for just in time learning and interpersonal communication of knowledge via knowledge management systems and networks of computer supported communication point to some differences to university approaches to e-learning that may provide avenues for research. Research on e-learning in university contexts must not ignore findings from previous studies of computers in teaching and learning, even work that used earlier more limited technologies. The focus should be on the more novel issues that are derived from industry perspectives on e-learning or those that are enabled specifically by the new levels of technological sophistication utilised in e-learning environments.

\section{REFERENCES}

Argyris, C., \& Schon, D., A. (1996). Organisational learning II: Theory, method, and practice. Reading, Massachusetts: Addison-Wesley.

ASTD, \& NGA. (2001). A vision of E-learning for America's workforce: Report of the Commission on Technology and Adult Learning. Retrieved 19/06/03, from $\mathrm{http}: / /$ www.masie.com/masie/researchreports/ELEARNINGREPORT.pdf

Brabazon, T. (2002). Digital hemlock: Internet education and the poisoning of teaching. Sydney, NSW: UNSW Press.

Brown, J. S., \& Duguid, P. (2000). The social life of information. Boston, Massachusetts: Harvard Business School Press.

Clark, J. (2000). Collaboration tools in online learning environments. Retrieved 25/09/02, from http://www.aln.org/alnweb/magazine/Vol4_issue1/Clark.htm

Clark, T. (2003). Disadvantages of collaborative online discussion and the advantages of sociability, fun and cliques for online learning. In McDougall, A., Murnane, J. S., Stacey, C., \& Dowling C. (Eds.), ICT and the Teacher of the Future: Selected Papers from the IFIP Working Groups 3.1 \& 3.3 Working Conference. Sydney: Australian Computer Society, 23-5.

Collis, B.A. (1994). Collaborative learning and CSCW: Research perspectives for internetworked educational environments. In Lewis. R. \& Mendelsohn, P. (Eds.), Lessons from Learning. Amsterdam: Elsevier: 81-104.

Garrison, D. \& Anderson, T. (2003). E-Learning in the $21^{\text {st }}$ Century: A framework for research and practice. New York: Routledge Falmer.

Greenagel, F. L. (2002). The illusion of e-learning: Why are we missing out on the promise of technology. Retrieved 21/06/03, from

http://www.league.org/publication/whitepapers/0802.html

Hara, N. \& Kling, R. (2000). Students' distress with a web-based distance education course: an ethnographic study of participants' experiences. Retrieved 26/09/02 from http://www.slis.indiana.edu/CSI/Wp/wp00-01B.html 
Hiltz, S. R. (1998). Collaborative learning in asynchronous learning networks: building learning communities. Retrieved 25/09/02 from http://eies.njit.edu/ hiltz/collaborative_learning_in_asynch.htm

Laurillard, D., \& McAndrew, P. (2002). Virtual teaching tools: Bringing academics closer to the design of e-learning. Retrieved 21/6/03 from http://www.shef.ac.uk/nlc2002/proceedings/symp/01.htm

Lave, J. \& Wenger, E. (1991). Situated learning: legitimate peripheral participation. Cambridge, U.K.: Cambridge University Press.

Mann, S. (2003). A personal inquiry into an experience of adult learning on-line. Instructional Science. 31, 111-125.

Mason, R. (2002). Review of e-learning for education and training. Retrieved 19/6/03 from http://www.shef.ac.uk/nlc2002/proceedings/symp/02.htm

McDonald, J. H. (1995). Te(k)nowledge: technology, education and the new student/subject. Science as Culture. 4(Part 3 (Number 20)), 535-564.

Murnane, J. S. (2003). Teaching Teaching with Information Technology. In McDougall, A., Murnane, J., Stacey, C. \& Dowling, C. (eds.) ICT and the Teacher of the Future. Sydney: Australian Computer Society, 89-91.

Palloff, R. M. \& Pratt, K. (2001). Lessons from the cyberspace classroom: The realities of online teaching. San Francisco: Jossey-Bass.

Salmon, G. (2000). E-moderating: the key to teaching and learning online. London: Kogan Page.

Salomon, G. (1993). No distribution without individual's cognition: a dynamic interactional view. In Salomon, G. (ed.), Distributed cognitions: psychological and educational considerations. Cambridge, U. K.: Cambridge University Press, 111-138.

Senge, P. M. (1992). The fifth discipline: the art and practice of the learning organisation. Milsons Point, NSW: Random House Australia.

Walsh, A. (2000). Traditional to flexible delivery (Working Paper 00-24). Sydney: University of Technology Sydney, Research Centre for Vocational Education and Training.

Wenger, E. (1998). Communities of practice: learning, meaning, and identity. Cambridge, U. K.: Cambridge University Press.

\section{BIOGRAPHY}

Anne McDougall, Ted Clark and Lyn Campbell are all members of the educational computing research group in the Department of Science and Mathematics Education at the University of Melbourne. E-learning in university education is currently a major research area for the group. Particular areas of interest for these authors include the socio-material networks of online learning and the role of text-based interaction in shaping teaching and learning practices online (Campbell), online media support for learning and the integration of online learning with social interaction practices (Clark), and design and evaluation of technology supported learning environments in a range of curriculum areas and educational settings (McDougall). 